\title{
O ensino de geografia e as relação étnico-raciais nos livros didáticos no ensino fundamental
}

\author{
Geographic teaching and ethnic-racial relations in the teaching books \\ in fundamental education
}

\author{
Alan Bizerra Martins', Marcelo Gaudêncio Brito Purezal"
}

\begin{abstract}
RESUMO
O presente trabalho tem como objetivo identificar e analisar os conteúdos referentes às relações étnico-raciais abordadas no livro didático de geografia do Ensino Fundamental, coleção Para Viver Juntos, $4^{a}$ edição, editora SM de 2015, utilizada por uma escola da rede Municipal de ensino de MarabáPA. A metodologia utilizada para a produção deste artigo é de cunho qualitativo e a partir do estudo realizado com base no referencial teórico trabalhado. A Coleção didática selecionada, de acordo com a proposta de análise da pesquisa, apresenta poucos conteúdos que podem ser trabalhados na abordagem, étnico e racial no ensino de Geografia. Contudo, em relação às figuras/imagens referentes às questões étnico- racial, não contribuem efetivamente para a construção de um conhecimento crítico sobre a temática abordada. Os livros didáticos voltados para o ensino de geografia na Educação Básica fazem pouca referência às abordagens e especificidades do campo das relações étnico-raciais e essas ausências de discussões sobre as questões envolvendo as relações étnico-raciais no ensino de geografia podem ocasionar no desconhecimento e na falta de criticidade na área de conhecimento da geografia.
\end{abstract}

Palavras-chave: Ensino de Geografia; Livro didático; Relações étnico-raciais

\section{ABSTRACT}

The present work aims to identify and analyze the contents related to the ethnic-racial relations addressed in the elementary school geography textbook, collection Para Viver Juntos, 4th edition, Publisher SM 2015, used by a school of the Municipal School of Marabá-PA. The methodology used for the production of this article is qualitative and based on the study based on the theoretical framework worked. The selected didactic collection, according to the research analysis proposal, presents few contents that can be worked on the ethnic and racial approach in the teaching of geography. However, in relation to the figures / images referring to ethnic and racial issues, they do not effectively contribute to the construction of a critical knowledge about the theme addressed. Textbooks focused on the teaching of geography in basic education make little reference to the approaches and specificities of the field of ethno-racial relations, and these lack of discussions on issues involving ethno-racial relations in geography teaching may lead to ignorance and lack of criticality in the area of geography knowledge.

Keywords: Geography Teaching; Textbook; Ethnic-racial relations

Graduado em Geografia na modalidade Licenciatura da Universidade Federal do Sul e Sudeste do Pará. E-mail: alanmartinsgeo14@gmail.com ORCID: https://orcid.org/0000-0002-2253-8894

"Professor assistente na Universidade Federal do Sul e Sudeste do Pará, Marabá, PA. E-mail: gaudecio@unifesspa.edu.br 


\section{INTRODUÇÃO}

O texto que se segue foi apresentado no terceiro semestre de 2018 como trabalho de conclusão de curso, na Universidade Federal do Sul e Sudeste do Pará, tendo como tema "As relações étnico-raciais nos livros didáticos de Geografia dos anos finais do Ensino Fundamental". Acreditamos ser importante refletir em novas possibilidades de práticas educativas sobre as relações étnicoraciais no ensino de Geografia. Contudo, buscamos demonstrar os resultados obtidos, para isso, lançamos duas inquietações da pesquisa: como os conteúdos referente a questão étnico-racial estão abordados nos livros didáticos de Geografia do $6^{\circ}$ ao $9^{\circ}$ ano no Ensino Fundamental? Esses conteúdos valorizam a cultura afro-brasileira e indígena?

Atualmente o debate sobre o Currículo vem ganhando novas perspectivas no âmbito educacional, principalmente devido às recentes propostas curriculares direcionadas às escolas, por exemplo, que indicam modificações nas configurações nos currículos da Educação Básica, assim tornando as questões curriculares como centro dos debates relativos às políticas educacionais. Algumas questões levantadas junto a tais reconfigurações buscam a discussão envolvendo a questão de negros/as e indígenas na esfera brasileira, entre outros grupos presentes no espaço da sociedade.

Para responder tais questionamentos, buscaremos auxílios pontuais nas propostas presentes na LDB (Lei de Diretrizes e Bases da Educação Nacional), especificamente, a Lei N. 10.639/03, 9 de janeiro de 2003 que trata sobre o ensino a obrigatoriedade da temática "História e Cultura Afro-Brasileira" e na BNCC (Base Nacional Comum Curricular) referentes ao debate sobre o reconhecimento das etnias, culturas e a questão racial.

O ensino de Geografia torna-se necessário também para pensar e problematizar a implementação e articulação do tema proposto pela lei 10.639/03, 11.645/08 e pela BNCC. Ou seja, não pensando em um ensino 
hegemonicamente eurocêntrico e colonial, o que reproduz apenas uma ideia de mundo que sustenta um padrão estético branco que auxilia na reprodução de relações de poder e instrumentos de controles sociais e comportamentais.

O livro didático é o material mais utilizado pelos professores nas escolas brasileiras, tanto particulares como nas públicas e, possivelmente, o único recurso pedagógico disponível para muitos docentes realizarem o processo de ensino e aprendizagem na formação dos alunos no ensino de Geografia, assim como das outras disciplinas escolares, torna-se imprescindível dar atenção especial a este artifício didático. Logo, apresenta-se o quanto é importante tal material educativo apresentar conteúdos/imagens de forma positiva relacionados as questões étnico-raciais e das diversidades.

O livro didático, a humanidade e a cidadania, na maioria das vezes, são representadas pelo homem branco e de classe média, invisibilizando a presença do negro/a, indígena e da mulher, como afirma Silva (2005, p. 27), "a mulher, o negro, os povos indígenas, entre outros, são descritos pela cor da pele ou pelo gênero, para registrar sua existência".

Sabendo que a Geografia realizando um ensino reflexivo, assim pode criar elementos para a desconstrução dos estereótipos negativos que são atribuídos aos negros, indígenas, pessoas LGBTT, etc., e com isso orientar os educandos a entenderem as complexidades das diversas visões de mundo.

Embora as leis 10.639/03 e 11.645/08 realizem o tratamento de conteúdos relacionados também às disciplinas de História e Artes, a Geografia, enquanto uma disciplina escolar, tem uma função essencial no âmbito das temáticas referentes às culturas afro-brasileira e indígenas, onde:

População negra e a cultura afro-brasileira, na medida em que propícia ao professor(a) condições de rever práticas e posturas, conceitos e paradigmas na construção de uma educação antirracista que preze a diversidade e a igualdade racial. (SOUZA, 2016, p. 71).

A metodologia utilizada para a pesquisa propõe uma análise de cunho qualitativo da Coleção Para Viver Juntos, organizada por Fernando dos Santos 
Sampaio, no qual, foram analisados os livros didáticos de Geografia voltados para o Ensino Fundamental do $6^{\circ}$ ao $9^{\circ}$ ano. A análise foi realizada a partir de uma ficha construída com alguns critérios do PNLD referente as questões étnicoraciais e indígenas. Os procedimentos metodológicos utilizados na construção da presente pesquisa foram: (I) Utilizando-se da técnica de pesquisa a análise de conteúdo nos livros didáticos; (II) a análise documental para os levantamentos bibliográficos referentes ao tema;(III) sistematização das informações da análise.

A pesquisa está estruturada em três momentos, onde o primeiro vem abordando o contexto das questões Étnico-raciais no âmbito educacional através de criação de leis e ações afirmativas, em segundo momento, a implementação da Lei 10.639/03 no ensino de Geografia e por fim, apresentação dos dados da verificação nos livros didáticos com reflexões na educação Geográfica e as considerações em relação à pesquisa.

O presente trabalho tem como objetivo identificar e analisar como os conteúdos referente as relações étnico-raciais são abordados na coleção Para Viver Juntos de livro didático de Geografia do Ensino Fundamental utilizada por escolas da rede Municipal de ensino de Marabá-PA.

\section{RELAÇÕES ÉTNICO-RACIAIS NO ÂMBITO EDUCACIONAL}

Segundo Marques e Calderoni (2016) as leis 10.639/03 e 11.645/08 representam um progresso referente às questões das relações étnico-raciais para a Educação Básica no Brasil. Através das referidas leis, promoveram-se ou criaram-se possibilidades de realizar a problematização da temática nos currículos das escolas. Nesse caso, as temáticas torna-se obrigatória nos currículos da Educação Básica enfatizando a importância da história e da cultura afro-brasileira, africana e indígena na formação dos educandos. Vale ressaltar que tais legislações são frutos da grande resistência e luta dos negros e indígenas promovidas através dos movimentos sociais. 
Sobre a abordagem das questões étnico-raciais no âmbito educacional, Gomes afirma:

[...] No contexto histórico e político brasileiro, as diferenças étnico-raciais foram naturalizadas, desnudadas da sua riqueza e transformadas em desigualdade. Dessa forma, quando a escola, a universidade e a política educacional colocam em pauta a discursão, as práticas, os projetos e as políticas voltadas para a diversidade étnico-racial, tendo como foco o segmento negro da população, o contexto da desigualdade se põe na ordem do dia e, em consequência disso, medidas para a superação precisam ser implementadas. (GOMES, 2011, p. 51).

Para Gomes ainda que esse contexto da desigualdade existe pelo motivo das questões raciais em nosso país seja uma problemática histórica, que embora no atual cenário já existam algumas medidas para combater esses tipos de situações, ainda há necessidade de ações que promovam o combate às desigualdades, visto que, o processo histórico do Brasil é marcada pelo racismo e discriminações, "especificamente contra populações de origem africana e indígena, impedindo, desta forma, seu pleno desenvolvimento econômico, político e social". (SIMÃO; BILÉSSIMO, 2014, p. 47).

Algumas mudanças que ocorreram por intermédio de políticas públicas implementadas nos últimos anos, especialmente ações afirmativas no âmbito educacional, favoreceram um incremento de leis como a 10.639/03 e a 11.645/08, assim, dando visibilidade a uma parcela considerável da população brasileira que até então estava marginalizada, da mesma forma, para confirmar "que as populações indígenas e de origem africana tenham espaço de estudo, a partir de dinâmicas próprias e expondo suas atuações enquanto sujeitos na formação do Brasil e do mundo" (LUCINDO, 2014, p. 73).

É possível salientar que os debates educacionais sirvam para criar políticas e/ou ações afirmativas para serem inseridas no âmbito educacional, cujo objetivo são as mudanças na história, garantindo o direito da condição humana da população indígena e de origem africana, “um exemplo é a lei. 10.639/03, em uma tentativa para resgatar a contribuição da população negra na construção da sociedade brasileira" (MULLER, 2009, p. 35). 
Apesar de a Lei Federal estar voltada para a inclusão da temática nos currículos das escolas públicas, existem ainda outros itens a serem implementados. Toda via, em estudos anteriores, Souza (2009, p. 79), demonstra que as diretrizes apontam três princípios para orientar, de forma geral, as ações dos sistemas de ensino e dos professores. São eles, “consciência política e histórica da diversidade; fortalecimento de identidade e de direitos e ações educativas de combate ao racismo e discriminação".

Apesar disso, Muller (2009, p. 33), acredita que em relação ao racismo e discriminação a dificuldade para tratar do tema ainda é maior, pois, há um despreparo por parte dos professores que atuam no âmbito educacional. Onde “os estudos enfatizam o despreparo dos professores, e de demais profissionais da educação, para trabalhar, do ponto de vista pedagógico, com situações de racismo declarado que ocorrem frequentemente no cotidiano escolar".

A falta da capacitação de profissionais da educação para a realização de trabalhos voltados para as relações étnico-raciais e diversidade cultural e outros temas, na grande maioria, é ausente em sua formação profissional, e que apontam a insuficiência de implementações de iniciativas e ações na área de formação inicial e continuada de professores.

Dessa maneira, Cardoso e Rascke (2014, p. 24), consideram a necessidade de ampliar ações e efetivar parcerias em outros âmbitos da escola e da gestão, sensibilizando para a importância de um ambiente escolar "capaz de compreender as relações étnico-raciais e que vislumbre história e cultura africana e afro-brasileira não apenas no mês de novembro, mas em todas as atividades escolares e, em especial no currículo".

Com a necessidade de ampliar ainda mais através de Leis e Ações afirmativas voltadas para as questões étnico-raciais. Desse modo, outro aspecto para problematizar como diz Candau (2012, p. 246) é “o caráter monocultural e o etnocentrismo que explicita ou implicitamente, que estão presentes na escola e impregnam os currículos escolares". No mesmo parágrafo a autora afirma que 
“desestabilizar a pretensa universalidade dos conhecimentos, valores e práticas que configuram as ações educativas e promover o diálogo entre diversos conhecimentos e saberes" (idem).

Ao retratar sobre os desafios para realizar o resgate da importância das diversas culturas e do processo de valorização e desconstrução do preconceito e da discriminação que estão em uma direção longa e difusa ao se tratar da realidade no âmbito educacional. Também, de realizar uma postura crítica sobre o caráter monocultural e do etnocentrismo, pois, estamos desafiados inclusive a valorizar e reconhecer as diversidades culturais com diversas práticas que as configuram no espaço para os diferentes grupos socioculturais.

Dessa maneira, a importância das Leis 10.639/03 e 11.645/08, como diz Gomes (2011, p. 56) "faz-se necessário mais do que o reconhecimento da ação dos(as) africanos(as) escravizados e dos negros e negras brasileiros como sujeitos históricos e socais e a inclusão desse debate nos processos e práticas de formação docente", portanto, tais legislações não podem ser interpretadas apenas como resposta do Estado às reivindicações dos movimentos sociais, mas principalmente, como elemento do cotidiano escolar.

\section{ENSINO DE GEOGRAFIA E A LEI 10.639}

No ano de 2003 ocorreu a implementação da Lei 10.639, uma ação afirmativa que torna obrigatório o desenvolvimento da inclusão do ensino da História da África e da Cultura Afro-Brasileira nos currículos dos estabelecimentos de Educação públicos e particulares para a Educação Básica. Assim, ocorreu uma alteração da Lei. 9.394/96, no que se refere a Lei de Diretrizes e Bases da Educação Nacional (LDBEN). Segundo (GOMES, 2013, p. 68) foi a partir do ano de 2003, a Lei 9.394/96 passa a prevalecer os seguintes Arts.: 26-A, 79-A e 79-B: 
Art. 26-A. Nos estabelecimentos de Ensino Fundamental e Médio, oficiais e particulares, torna-se obrigatório o ensino sobre História e Cultura AfroBrasileira (Incluído pela Lei 10.639, de 09/01/2003).

$\S 1^{\circ} \mathrm{O}$ conteúdo programático a que se refere o caput deste artigo incluirá o estudo da História da África e dos africanos, a luta dos negros no Brasil, a cultura negra brasileira e o negro na formação da sociedade nacional, resgatando a contribuição do povo negro nas áreas sociais, econômica e política pertinentes à História do Brasil (incluído pela Lei 10.639, de 09/01/2003).

$\S 2^{\circ}$ Os conteúdos referentes à História e Cultura Afro-Brasileira serão ministrados no âmbito de todo o currículo escolar, em especial nas áreas de Educação Artística e de Literatura e História Brasileira (incluído pela Lei 10.639, de 09/01/2003).

Art. 79-A. (VETADO) (incluído pela Lei 10.639, de 09/01/2003).

Art. 79-B. O calendário escolar incluirá o dia 20 de novembro como Dia Nacional da Consciência Negra. (incluído pela Lei 10.639, de 09/01/2003).

Através da implementação da lei 10.639 a preocupação deve ser tomada por partes dos professores não somente da disciplina de História e Artes, mas também das outras, como é o caso da Geografia, busca contemplar os conteúdos referentes as relações étnico-raciais, além disso, rever os currículos, os temas/temáticas e práticas de ensino/pedagógicas.

No ensino de Geografia, ao abordar os conteúdos étnico-raciais, deve-se ensejar que mulheres e homens, os negros e indígenas também são sujeitos de transformação do espaço geográfico, assim como, são construtores de espacialidades, de territórios e territorialidades próprias, paisagens e lugares marcados por culturas ancestrais, conforme Santos (2009, p. 22), que "no intuito de que este saber, fundamental na construção de visões de mundo e comportamentos e posicionamento, contribua com o projeto de educar para a igualdade racial".

A escola como agência promotora da formação educacional de todos os cidadãos, tem como um de seus papeis realizar um trabalho em prol do fortalecimento das culturas e/ou de novos significados para o negro, o indígena, 
as identidades de gênero, as opções religiosas, entre outras características que compõem a peculiaridade de cada sujeito, o que a torna um ser diverso, com direitos igualitários, pois, “cabe à escola em seu processo formativo, desenvolver uma educação voltada para sujeitos para que apresentem concepções humanas mais abrangentes e valorativas da pessoa" (MARTINS; GOMES, p. 01, 2016).

Considerando uma educação voltada para a construção de uma sociedade na perspectiva da igualdade e justiça social no Brasil, é fundamental a introdução no ensino de Geografia da temática sobre as relações étnico-raciais com intenção de rever posições e visões referente aos vários mundos étnicos. Dessa maneira, a participação na educação voltada para as questões raciais são fundamentais para o processo de ensino aprendizagem não somente na Geografia, mas em outras disciplinas que fazem parte do currículo escolar.

Nessa perspectiva os desafios para que o ensino de Geografia, enquanto ciência, não é apenas a maneira de realizar transmissão do conhecimento científico, mas de outros processos fundamentais no processo de formação humana, tais como seus espaços de socialização e interação com o meio vivido. Nessa situação, Santos (2009) aborda que o ensino das relações étnico-raciais na Geografia:

[...] se acreditarmos que a raça é um elemento que regula as relações sociais, de alguma forma suas manifestações estão imbricadas na Geografia, e por isso seu ensino deve atentar para tal fato social sem suas múltiplas espacialidades. [...] uma reflexão acerca da inserção da temática racial no ensino de Geografia torna forçoso, portanto, uma reflexão acerca do(s) sentido(s) de aprender/ensinar Geografia, pois é o sentido, enquanto manifestações de visões de mundo e de projetos societários, que orienta a práxis, é ele que vai definir a forma como tal temática é (ou não) abordada. (SANTOS, 2009, p. 25).

Neste caso a que se refere, o ensino das relações sociais está relacionado com a abordagem racial, e necessariamente a Geografia deve contemplar através 
dessas duas perspectivas para realizar a compreensão das expressões espaciais. Assim sendo, "o ensino de Geografia fornece não apenas novos temas a serem trabalhados no ensino escolar de Geografia, mas também a reflexão da implementação da Lei 10.639". (SANTOS, 2009, p. 30).

O ensino de Geografia é a área do conhecimento, comprometida em tornar o mundo e suas dinâmicas compreensíveis aos estudantes, dar explicações para as mudanças territoriais e apontar soluções e reflexões para uma organização espacial, portanto, a Geografia é uma disciplina fundamental na "formação da cidadania do povo brasileiro, que apresenta uma heterogeneidade singular na sua composição étnica, socioeconômica e na distribuição espacial". (ANJOS, 2005, p. 177).

Neste caso, acreditamos ser importante pensarmos essa disciplina ao assumir grande importância dentro da temática da pluralidade cultural no processo de ensino, sobretudo no que diz respeito "às características dos territórios dos diferentes grupos étnicos e culturais que convivem no espaço. Assim, como aponta as espacialidades das desigualdades socioeconômicas e excludentes que permeiam a sociedade brasileira". (ANJOS, 2005, p. 179).

\section{RESULTADOS E DISCUSSÕES}

\subsection{Análise dos conteúdos dos livros didáticos}

A coleção Para Viver Juntos do Ensino Fundamental do $6^{\circ}$ ao $9^{\circ}$ ano, possui quatro volumes. O livro didático do $6^{\circ}$ ano da coleção está dividido em nove unidades, o qual cada possui três a quatro módulos. Os conteúdos estão da seguinte forma: 
Quadro 01: Conteúdo do livro do $6^{\circ}$ ano.

\begin{tabular}{|l|l|}
\hline \multicolumn{1}{|c|}{ UNIDADES } & \multicolumn{1}{c|}{ MÓDULOS } \\
\hline PAISAGEM E LUGAR & Paisagem; lugar e espaço vivido. \\
\hline ORIENTAÇÃO E LOCALIZAÇÃo & Orientação; localização. \\
\hline INTERPRETAÇÃO CARTOGRÁFICA & Aprendendo a ler mapa; representações cartográficas. \\
\hline O PLANETA TERRA & $\begin{array}{l}\text { A terra no Sistema Solar; os principais movimentos da } \\
\text { terra. }\end{array}$ \\
\hline A CROSTA TERRESTRE & A terra; combustíveis fósseis; os solos. \\
\hline FORMAÇÃO E MODELAGEM DO RELEVO TERRESTRE & $\begin{array}{l}\text { Agentes externos: intemperismo e erosão; agentes } \\
\text { internos: as placas tectônicas; agentes internos: vulcões e } \\
\text { abalos sísmicos; as unidades de relevo. }\end{array}$ \\
\hline A HIDROSFERA TERRESTRE & $\begin{array}{l}\text { A água na terra; o uso das águas oceânicas; as águas } \\
\text { continentais. }\end{array}$ \\
\hline A ATMOSFERA TERRESTRE & $\begin{array}{l}\text { A atmosfera; elementos atmosféricos; dinâmicas } \\
\text { climáticas; poluição atmosférica e suas consequências. }\end{array}$ \\
\hline A BIOSFERA & $\begin{array}{l}\text { A composição da biosfera; os ambientes naturais e a ação } \\
\text { do ser humano; }\end{array}$ \\
\hline O livro é o menor possui um total de 224 páginas. & \\
\hline
\end{tabular}

Quadro 02: Conteúdo do livro do $7^{\circ}$ ano.

\begin{tabular}{|c|c|}
\hline UNIDADES & MÓDULOS \\
\hline O TERRITÓRIO BRASILEIRO & $\begin{array}{l}\text { Características gerais do Brasil; formação do território } \\
\text { brasileiro; a divisão política do Brasil. }\end{array}$ \\
\hline A POPULAÇÃO BRASILEIRA & $\begin{array}{l}\text { A formação do povo brasileiro; distribuição da população; } \\
\text { dinâmica populacional; população em movimento. }\end{array}$ \\
\hline TRABALHO, CONSUMO E SOCIEDADE & $\begin{array}{l}\text { O mercado de trabalho; sociedade e desenvolvimento; } \\
\text { consumo e infraestrutura. }\end{array}$ \\
\hline BRASIL RURAL & $\begin{array}{l}\text { Características da agricultura no Brasil; modernização do } \\
\text { campo; problemas no mundo rural. }\end{array}$ \\
\hline INDÚSTRIA & $\begin{array}{l}\text { Industrialização; indústria e atividade econômica; energia e } \\
\text { indústria; concentração industrial e expansão da indústria. }\end{array}$ \\
\hline A URBANIZAÇÃO BRASILEIRA & $\begin{array}{l}\text { Urbanização e migração; transporte; urbanização e } \\
\text { modernização da comunicação. }\end{array}$ \\
\hline AS REGIÕES SUDESTE E SUL & $\begin{array}{l}\text { Região Sudeste: características gerais; sudeste: cidade e } \\
\text { economia; região Sul: aspectos gerais; a economia da região } \\
\text { Sul. }\end{array}$ \\
\hline AS REGIÕES NORTE E CENTRO-OESTE & $\begin{array}{l}\text { Região Norte: aspectos gerais; região Norte: atividades } \\
\text { econômicas; região Centro-Oeste: aspectos gerais; região } \\
\text { Centro-Oeste: atividades econômicas. }\end{array}$ \\
\hline REGIÃO NORDESTE & $\begin{array}{l}\text { Características gerais; atividades econômicas; população e } \\
\text { qualidade de vida. }\end{array}$ \\
\hline
\end{tabular}


Quadro 03: Conteúdos do livro do $8^{\circ}$ ano.

\begin{tabular}{|c|c|}
\hline UNIDADES & MÓDULOS \\
\hline MUNDO DE DIFERENÇAS & $\begin{array}{l}\text { Diferentes formas de regionalizar o mundo; indicadores } \\
\text { de desenvolvimento; o mundo bipolar e a "nova ordem" } \\
\text { dos anos } 1990 .\end{array}$ \\
\hline MUNDO GLOBALIZADO & $\begin{array}{l}\text { A transformação do espaço geográfico mundial; } \\
\text { comércio: conflito de interesses entre países ricos e } \\
\text { países pobres; efeitos da globalização. }\end{array}$ \\
\hline O MUNDO NO SÉCULO XXI: POPULAÇÃO E DESAFIOS & $\begin{array}{l}\text { População mundial: distribuiç̧ão e tendências; o desafio } \\
\text { energético; os desafios ambientais e os geopolíticos }\end{array}$ \\
\hline AMÉRICA: ASPECTOS GERAIS & $\begin{array}{l}\text { Diversidade regional; a colonização europeia da América; } \\
\text { características naturais do continente americano }\end{array}$ \\
\hline AMÉRICA DO NORTE & $\begin{array}{l}\text { Estados Unidos da América; a economia dos Estados } \\
\text { Unidos; Canadá; México. }\end{array}$ \\
\hline AMÉRICA DO SUL E AMÉRICA CENTRAL & $\begin{array}{l}\text { América do Sul; A economia de alguns países sul- } \\
\text { americanos; América Central. }\end{array}$ \\
\hline ÁFRICA: UM CONTINENTE DE CONTRASTES & $\begin{array}{l}\text { África: aspectos naturais; o imperialismo e a partilha da } \\
\text { África. }\end{array}$ \\
\hline ÁFRICA: DESENVOLVIMENTO ECONÔMICO & $\begin{array}{l}\text { A economia africana; Investimentos estrangeiros e } \\
\text { desenvolvimento econômico; economia regional }\end{array}$ \\
\hline ÁFRICA: POPULAÇÃO E URBANIZAÇÃO & $\begin{array}{l}\text { A população; o crescimento da população; o rural e o } \\
\text { urbano no continente africano. }\end{array}$ \\
\hline
\end{tabular}

Quadro 04: Conteúdos do livro do $9^{\circ}$ ano.

\begin{tabular}{|l|l|}
\hline \multicolumn{1}{|c|}{ UNIDADES } & \multicolumn{1}{c|}{ MÓDULOS } \\
\hline EUROPA: ASPECTOS FÍSICOS E NATURAIS & $\begin{array}{l}\text { A constituição do continente europeu; relevo e rios } \\
\text { europeus; clima e vegetação na Europa. }\end{array}$ \\
\hline $\begin{array}{l}\text { FORMAÇÃO TERRITORIAL, POPULAÇÃO E E } \\
\text { URBANIZAÇÃO EUROPEIA }\end{array}$ & $\begin{array}{l}\text { A formação da Europa contemporânea; a União Europeia; } \\
\text { a população europeia; a urbanização europeia. }\end{array}$ \\
\hline EUROPA OCIDENTAL & $\begin{array}{l}\text { As grandes potências econômicas e a industrialização } \\
\text { clássica; a Europa Ocidental: do Estado do bem-estar } \\
\text { social à crise econômica; Europa Mediterrânea. }\end{array}$ \\
\hline RÚSSIA E EUROPA OCIDENTAL & $\begin{array}{l}\text { A Rússia e o fim da União Soviética; o leste europeu; } \\
\text { economia do Leste europeu; a ex-lugoslávia. }\end{array}$ \\
\hline ÁSIA: ASPECTOS GERAIS & $\begin{array}{l}\text { Revelo e rios asiáticos; clima e vegetação; população e } \\
\text { diversidade regional. }\end{array}$ \\
\hline O LESTE E O SUDESTE ASIÁTICOS" & $\begin{array}{l}\text { Japão; China: um país continental; a indústria chinesa; os } \\
\text { Tigres Asiáticos. }\end{array}$ \\
\hline ÁSIA CENTRAL E MERIDIONAL & Ásia Central; Ásia Meridional; Índia \\
\hline ORIENTE MÉDIO & $\begin{array}{l}\text { Características gerais; o petróleo no Oriente Médio; } \\
\text { conflitos e questões territoriais. }\end{array}$ \\
\hline OCEANIA E REGIÕES POLARES & $\begin{array}{l}\text { Bases naturais e povoamento da Oceania; economia da } \\
\text { Austrália e da Nova Zelândia; Regiões Polares. }\end{array}$ \\
\hline O livro pOSSUi Um total de 256 páginas. & \multicolumn{1}{|c|}{} \\
\hline
\end{tabular}

\subsection{Análise referente as questões Étnico-Raciais no livro didático}

Referente a análise da coleção dos livros didáticos foi utilizada uma ficha com total de cinco perguntas que buscou contribuir para obter as informações necessárias para a compreensão e verificação de qual modo os temas referentes 
as relações étnico-raciais estão presentes nas unidades. O critério foi referente aos conteúdos e ilustrações que abordassem a temática estudada.

Aborda a temática das relações étnico-raciais, do preconceito, da discriminação racial e da violência correlata, visando à construção de uma sociedade antirracista, solidária, justa e igualitária?

O livro do $6^{\circ}$ ano não apresenta os conteúdos especificamente voltados para a temática referente a questão étnico-racial, porém, diferente dos demais livros da coleção, ocorrem somente o debate do assunto sobre as questões indígenas. Os temas são abordados em dois momentos no livro na seção “Mundo Aberto", tal segmento tem objetivo debater sobre conteúdo da cultura e o respeito da diferença. No final do capítulo 3, intitulado "Cartografia indígena: uma maneira diferente de criar mapas" na página 57, apresenta-se um texto que retratam sobre as técnicas indígenas da cartografia que a utiliza para construir cartas e plantas de suas terras e passam para o papel a memória guardada de muitas gerações sobre o meio onde vive.

Em outro momento, a temática é abordada no início do capítulo 6, intitulado “O parque Indígena do Xingu: O parque ontem e hoje” na página 117, texto que retrata o conteúdo voltado sobre os indígenas abordando sobre o povo Kamayurá que vive na região Centro-Oeste do Brasil. O assunto reflete sobre a importância do parque para este povo, que lutam para conseguir manter sua cultura de acordo com os seus costumes.

No livro do $7^{\circ}$ ano, na segunda unidade, o tema das relações étnico-raciais é abordado e intitulado "A formação do povo brasileiro" na página 38, o qual apresenta estatísticas do IBGE 2010, destacando que a presença de descendentes dos africanos é fortemente situada na região Nordeste e Sudeste no Brasil devido ao sistema histórico de colonização. Na página 40, sobre "a população negra", 0 livro aborda sobre as desigualdades econômicas, sendo que o negro e os indígenas sofrem o processo de exclusão, o assunto destaca que o principal motivo dessa desigualdade é devido ao processo histórico. 
Na mesma unidade apresenta o assunto relacionado a "povos indígenas", onde destaca que o número da presença de etnias é baixo devido ao genocídio provocado pelos europeus no período da colonização, e a luta dessas comunidades para a demarcação de suas terras contra a invasão de madeireiros e fazendeiros que exploram as riquezas da terra.

Por fim, outro momento do livro destaca na página 81 intitulada “os negros no Brasil: a luta contra o racismo" que apresenta o contexto de uma longa aplicação dos negros contra o racismo e preconceito. O livro também cita brevemente algumas conquistas recentes dos movimentos, uma delas é a Lei. N. 10.639/03 o que torna obrigatório o ensino de história e cultura africana e Afrobrasileira nas escolas públicas no Brasil. Por fim, na página 219 intitulada “Aliança dos povos da floresta: os negros da Amazônia", destaca que nem todos sabem que na Amazônia possui também uma população negra e afro-brasileira e indígena.

O tema das relações étnico-raciais no livro do $8^{\circ}$ ano é abordado no 9 capítulo intitulado "África: população e urbanização", o qual apresenta um texto na seção "mundo aberto" na página 221 "As mulheres africanas: luta pela igualdade de direitos", o trecho aborda sobre o movimento das mulheres negras em países marcados por conflitos que ocorrem enormes desigualdades sociais. Diante disso, as mulheres em uma tentativa de aumentar sua participação da vida política estão se organizando a partir de movimentos e grupos sociais com objetivos de defender o direito de ampliar a sua autonomia.

O livro de forma geral, apresenta pouco conteúdo, pois, a temática foi encontrada somente na seção "mundo aberto" que retrata especificamente da abordagem racial. Vale ressaltar que, em sua estrutura, o livro possui 3 capítulos voltados para o continente Africano, porém, os conteúdos são focados praticamente em temas como: relevo, economia, população, conflitos políticos entre outros. 
Por fim, no livro do $9^{\circ}$ ano, o tema é abordado na página 83, "A importância da contribuição africana para o Brasil, Portugal e Espanha", demonstra o relevante papel dos africanos no período da colonização quando explica que "é necessária para ilustrar a complexidade e a importância da bagagem africana trazida para o Brasil, e também levada, antes de 1500, para Portugal e Espanha". Em outro momento o conteúdo referente a temática aparece na página 225, "Indígenas vivem em faixa de gaza brasileira", o trecho está refletindo sobre a dificuldade de abrigar a população indígena para sua reprodução física e cultural. Vale ressaltar, que os conteúdos encontrados foram novamente na seção "mundo aberto" que especificamente retrata sobre a temática da valorização da pluralidade cultural.

Promove positivamente a cultura afro-brasileira e dos povos indígenas brasileiros, dando visibilidade aos seus valores, tradições, organizações e saberes sócios científicos, além de considerar seus direitos e sua participação em diferentes processos históricos que marcam a formação do espaço geográfico brasileiro?

De certa forma os temas sobre a cultura afro-brasileira não foram abordados no livro do $6^{\circ}$ ano da coleção, enquanto, sobre os povos indígenas são colocados seus conhecimentos e saberes sócios científicos quando o texto "Cartografia indígena: uma maneira diferente de criar mapas" aborda as técnicas que os indígenas utilizam para realizar estudos da área, esses lugares onde os animais vão para se alimentar, também utilização para marcar trilhas utilizadas por pessoas próximas aos rios. Diante disso, vemos que o uso da ferramenta da cartografia também é utilizado pelos povos indígenas, de uma forma diferente, mas muito produtiva e significativa. O texto perfeitamente promove a cultura e vai além, através das representações cartográficas, mostra a organizações e valores indígenas.

No livro do $7^{\circ}$ ano na página 38, intitulado "A formação do povo brasileiro", vem abordando a importância da população indígena presente no período da 
colonização, porém, ao destacar os negros, retrate-se sobre o processo de escravidão que esses africanos passavam pelo sistema do navio negreiro no período colonial. Ainda no capítulo, apresenta-se conteúdo sobre os povos indígenas, onde o censo de 2010 sobre a caracterização da distribuição indígena no Brasil, tem cerca de 305 etnias com 217 línguas distribuídas pelo território nacional. No mesmo texto, apresenta a importância da constituição de 1988 para os povos indígenas no Brasil, que passaram a ter direito pelas suas terras e falar em sua própria língua livremente sua cultura.

O livro do $8^{\circ}$ ano da coleção é o mais contraditório do conjunto, pois, ao abordar três capítulos dedicados ao continente Africano, porém, ao destacar a representação da cultura africana apenas em uma única vez. Também, não é abordado em nenhum momento o tema, além do livro ter a seção que tem objetivo de expor a pluralidade cultural, e não apresenta entre os capítulos. Diante disso, o livro não consegue promover a valorização da cultura afrobrasileira e principalmente dos povos indígenas devidas a esta limitação do conteúdo.

O livro do $9^{\circ}$ ano, a página 83 quando aborda na seção "Lendo Geografia", “Os africanos vieram com conhecimentos técnicos e tecnológicos superiores aos dos europeus e aos dos indígenas para as atividades produtivas desenvolvidas no país no período de Colônia e Império (...)". Diante disso, além de quebrar tal pensamento que os africanos somente vieram sem conhecimento algum e para ficar apenas realizar o trabalho escravo, o livro de certa forma quebra esta convicção ao colocar no texto dessa maneira a questão do processo da contribuição da África para o Brasil.

Os conteúdos são adequados e enriquecedores no intuito de ampliar as possibilidades de expressão do aluno a respeito das questões Étnico-raciais?

De acordo com os textos apresentados no livro do $6^{\circ}$ ano, as temáticas são importantes e com bastantes elementos abordados sobre os costumes, saberes e valorização da cultura, como ocorre no texto sobre a cartografia indígena. Dessa 
forma, quando os assuntos ao fazerem esse tipo de abordagem podem estabelecer que os alunos compreendam e também valorize a cultura indígena. Um exemplo, na página 57, no texto sobre a cartografia indígena e explica da seguinte forma, "os alunos podem construir mapas do lugar onde vivem. Com esses mapas, os indígenas podem programar melhor como vão proteger seu território, fazer suas plantações e organizar as demais atividades".

No livro do $7^{\circ}$ ano apesar de ser abordado o conteúdo referente a questão étnico-racial, aparece poucas vezes durante as unidades, ainda assim é enriquecedor, pois, é capaz de gerar discussão e o debate com o aluno. Enquanto, o assunto é abordado dessa maneira, em outros momentos ele se aprofunda, fazendo que os alunos possam refletir sobre o tema apresentado no livro.

Na página 81 quando é explicado sobre a luta contra o racismo no Brasil a maioria das pessoas negras recebiam salários mais baixos e ter menor escolaridade, e que os jovens negros são também vítimas de violência, faz com que os alunos reflitam sobre o fato desses grupos sofrerem exclusão na sociedade pela questão racial. Na mesma página ocorre uma proposta de atividade em grupo que o livro destaca “Em sua opinião: existe racismo no Brasil?", com esse questionamento os alunos vão criar possibilidades de analisar o processo histórico e de verificar dado que só o negro e indígena são excluídos socialmente, assim os estudantes podem buscar o interesse pelo tema com esta sugestão de exercício.

O livro do $8^{\circ}$ ano é apresentado de forma simples e insuficiente, a temática das relações étnico-raciais não tem como ampliar e muito menos criar possibilidade para o aluno se interessem pelo tema. Pois, o assunto abordado retrata sobre a questão das lutas de classes, como as mulheres africanas pelo direito no âmbito da política. O assunto é importante, porém, não está adequado que faça o aluno valorizar o que está escrito no livro didático, e também devido o 
restante do conteúdo, pois, não há outra discussão da temática em nenhum outro momento no material.

Na página 221, o texto é bastante curto sobre o tema das “mulheres africanas: lutas pela igualdade de direito" faz uma breve e resumida explicação, e já parte para outro abordando sobre a importância da Wangari Maathai a líder queniana da defesa do meio ambiente e dos direitos das mulheres. Diante disso, a situação do texto torna-se um pouco fragmentado o que pode fazer o aluno ter dificuldade na interpretação.

Apesar de ser abordado a questão étnico-racial em apenas duas vezes no livro do $9^{\circ}$ ano como nos demais da coleção, pode gerar discussão e debate com o aluno. Na página 83 quando aborda sobre a importância da África para os três países, Brasil, Portugal e Espanha explica sobre o processo histórico que ocorreu no território brasileiro, retratando além do sistema de escravidão, mas também dos saberes destes sujeitos que eram trazidos para o Brasil. Sendo assim, o aluno principalmente através do texto presente na página irá de certa forma reavaliar sobre tudo aquilo que já foi construindo referente aos escravos e posteriormente a respeito das questões étnico-raciais.

Incentiva a ação pedagógica voltada para o respeito e valorização da diversidade, dos princípios da sustentabilidade e da cidadania ativa, apoiando práticas pedagógicas democráticas e o exercício do respeito e da tolerância?

No livro do $6^{\circ}$ ano somente abordou o assunto na seção "mundo aberto" sobre os indígenas, de certa forma, as informações contidas também favorecem sobre a valorização da cultura. Toda via, apesar de ser abordado apenas duas vezes no livro todo, nesses dois momentos através dessas informações é capaz de gerar questionamentos importantes. Sendo assim, ainda é pouco principalmente referente a questão da valorização da diversidade cultural e o exercício ao respeito. Apesar disso, o livro tem várias possibilidades de realizar ações pedagógicas individuais ou em grupos com os alunos em sala de aula. 0 
professor tem possibilidade realizar práticas pedagógicas que valorizem a cultura apresentada na unidade.

Na página 57, ocorre apresentação do tema em relação à cartografia indígena e sua importância, logo após também com uma proposta de atividade referente a temática, "Com base no texto, escreva no caderno quais são os principais benefícios que a cartografia indígena pode proporcionar?". Diante disso, além do texto base o aluno poderá aprofundar o seu entendimento sobre o assunto, e o livro cria uma oportunidade de realizar uma ação pedagógica com os alunos.

De certa forma, as informações contidas no livro do $7^{\circ}$ ano da coleção favorecem sobre a valorização da cultura afrodescendente e afro-brasileira. Com tudo, em alguns momentos as informações são capazes de gerar o questionamento no aluno. O conteúdo presente no livro é pouco principalmente referente a questão da valorização da diversidade cultural. No entanto, no livro tem várias possibilidades de realizar ação pedagógica tanto individual ou em grupos com os alunos em sala de aula. As temáticas estão voltadas principalmente em processos históricos como o processo de miscigenação e também da luta sobre o racismo e discriminação. Diante disso, cabe ao professor realizar práticas pedagógicas que valorizem a cultura apresentada na unidade.

Na página 40, há um boxe de atividade no início da unidade "verifique o que aprendeu" onde faz questionamento para o aluno com as seguintes indagações: "quais são os grupos formadores do povo brasileiro?"; "caracterize etnicamente a população brasileira?"; "qual é a principal causa da desigualdade socioeconômica entre a população branca e a população de origem negra e indígena no Brasil?"; "Como ocorreu a introdução dos negros africanos no Brasil? Em quais regiões há maior número de afrodescendentes?". Essas indagações que o livro sugere logo no início do capítulo da possibilidade de realizar práticas visando buscar o entendimento de uma sociedade democrática e justa. 
O livro do $8^{\circ}$ ano apesar de o conteúdo é apresentado no capítulo 9 na seção "mundo aberto" o texto favorece duas questões importantes. A primeira, ao abordar o tema da desigualdade racial, e também do alto grau de contraste entre os homens e mulheres. A segunda, explica sobre o processo que as mulheres negras vêm realizando através dos movimentos negros e grupos feministas e organizações, cujo objetivo e criar e ampliar os seus direitos e ter sua própria autonomia. Diante disso, através do assunto abordado há possibilidade para ação pedagógica visando uma construção de pensamento onde o aluno pratique o exercício de respeito.

Através do texto na seção "mundo aberto" gera possibilidade de questionamento aos alunos referente a temática apresentada. Também, o livro não dar oportunidade de se aprofundar o texto com apenas uma questão, como na página 221 destaca “Por que é importante que as mulheres participem da política e do governo?". A pergunta esquece um pouco sobre o que foi abordado no texto, pois, na mesma página abordar-se sobre que o país possui uma grande diversidade étnica, cultural, social e política. Sendo assim, ficou a escassez com apenas uma pergunta sobre tema abordado.

As informações contidas no livro do $9^{\circ}$ ano da coleção favorecem a valorização da cultura afrodescendente e afro-brasileira. Apesar de ser abordado apenas duas vezes no livro, nesses dois momentos as informações são capazes de criar o questionamento ao aluno. Entretanto, no livro tem várias possibilidades de realizar ação pedagógica com os alunos em sala de aula.

Na página 83, através do texto de apoio, ocorre uma proposta “De olho no texto", tal sugestão apresenta duas questões norteadoras para os alunos referente a temática, explique com suas palavras este trecho do texto: “o Brasil é em grande escala consequência do conhecimento e da experiência histórica dos africanos?" e "Em que lugares, além do Brasil, a cultura africana teve influência?". Com essas perguntas o professor e o aluno podem debater a respeito e da 
valorização da cultura afrodescendente não apenas no Brasil, mas em outros países.

Ilustrações reproduzem adequadamente a diversidade étnica da população brasileira, a pluralidade social e cultural do país, não expressando, induzindo ou reforçando preconceitos e estereótipos?

As ilustrações presentes no livro do $6^{\circ}$ ano são retratadas somente três vezes, na primeira, onde ocorre uma representação de indígenas Paiter (figura 1) usando o GPS em seus celulares para monitorar o desmatamento em seu território, outra imagem representa cartografia indígena, por fim temos uma da Aldeia Kamayurá. Diante disso, as ilustrações apesar de serem poucas nos conteúdos, estão adequadas para a representatividade da cultura indígena. Vale ressaltar, novamente em que no livro da coleção não foi identificada nenhuma outra imagem que represente sobre a temática referente a questão étnico-racial, que remete fazer uma observação, nesse aspecto o assunto do $6^{\circ}$ ano, deixa um pouco de lado ao representar a diversidade étnica da população brasileira.

\section{Figura 1: ilustração dos indígenas Paiter usando GPS.}

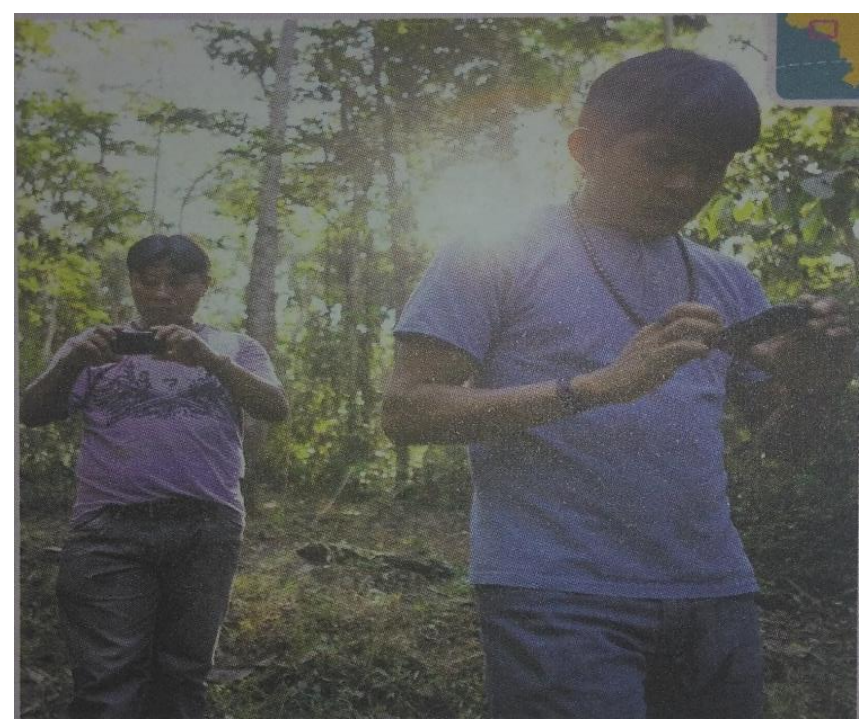

Fonte: Livro Didático do 6ª ano, 2018. 
Figura 2: Ilustração sobre a cartografia indígena.

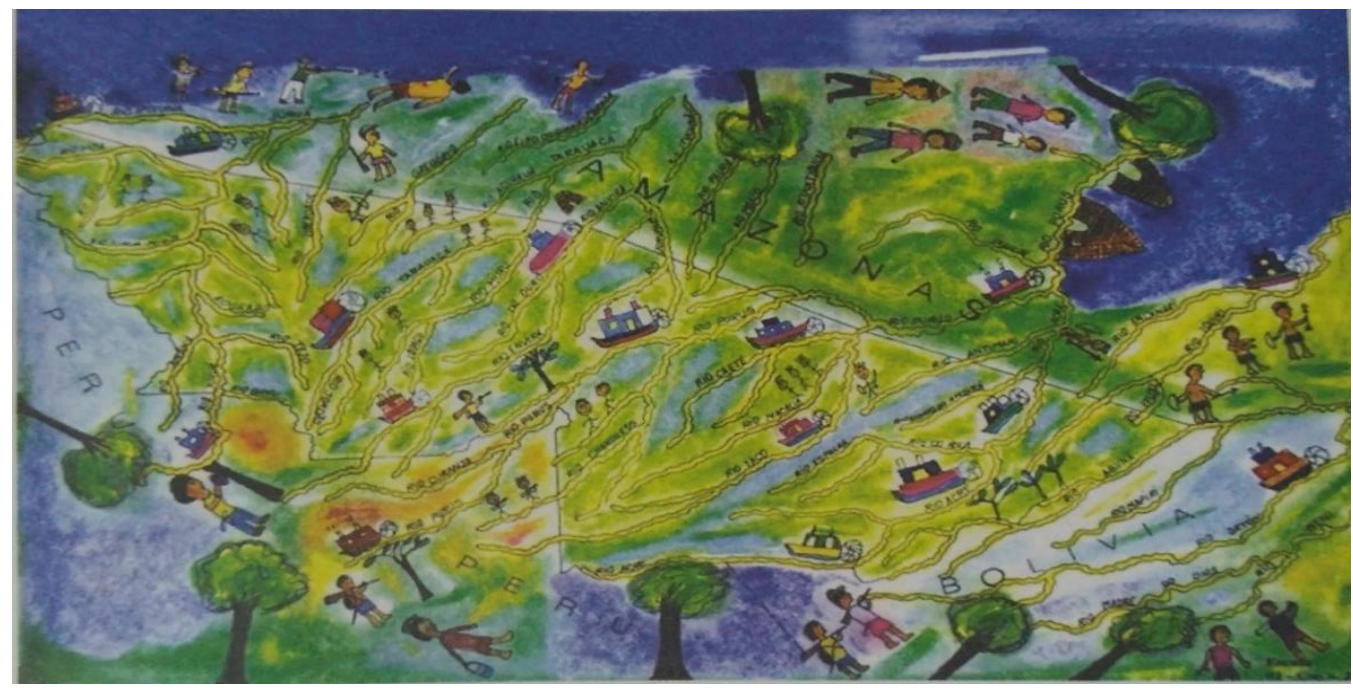

Fonte: Livro Didático do 6ª ano, 2018.

Figura 3: Ilustração sobre os Indígenas Kamauyrá no Xingu, Mato Grosso.

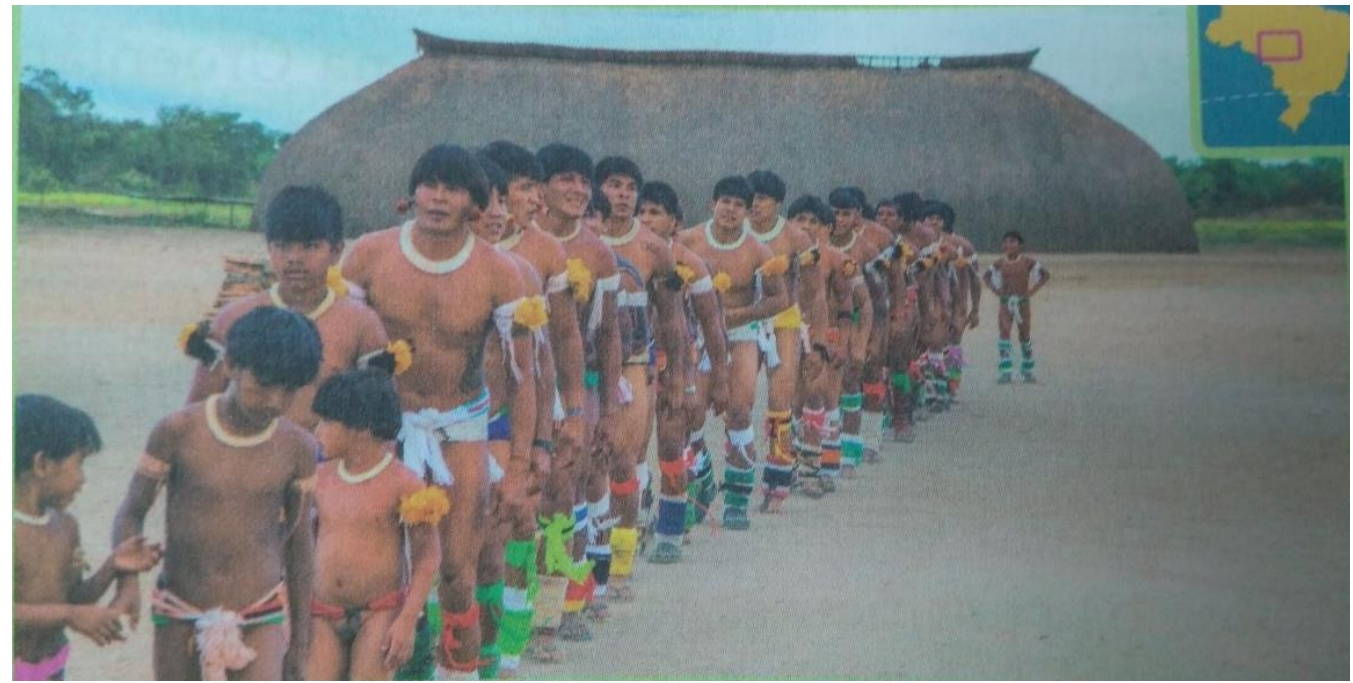

Fonte: Livro Didático do 6º ano, 2018.

No livro do $7^{\circ}$ ano, as presentes ilustrações retratam de forma positiva na questão da diversidade étnica no Brasil e da valorização da cultura afrodescendente e afro-brasileira. Na 3 unidade na página 81, imagem representa a comemoração do dia da Consciência Negra, onde simboliza as lutas e conquistas contra a desigualdade e o racismo no Brasil, a ilustração também tem significado sobre a prática da capoeira, onde é uma expressão cultural brasileira, que possui mistura de arte marcial, música e cultura popular. 
Figura 4: Ilustração sobre o dia da Consciência Negra no Brasil.

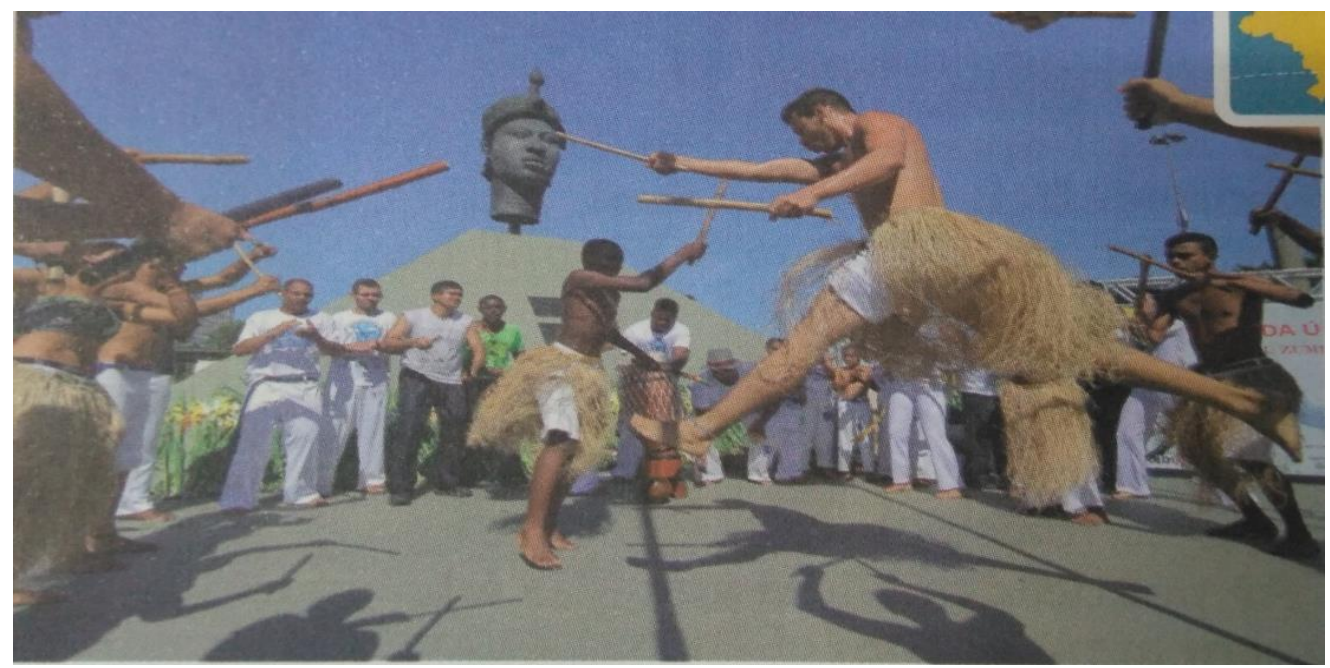

Fonte: Livro Didático do $7^{\circ}$ ano, 2018.

Figura 5: Ilustração sobre as crianças indígenas da aldeia do Ahima.

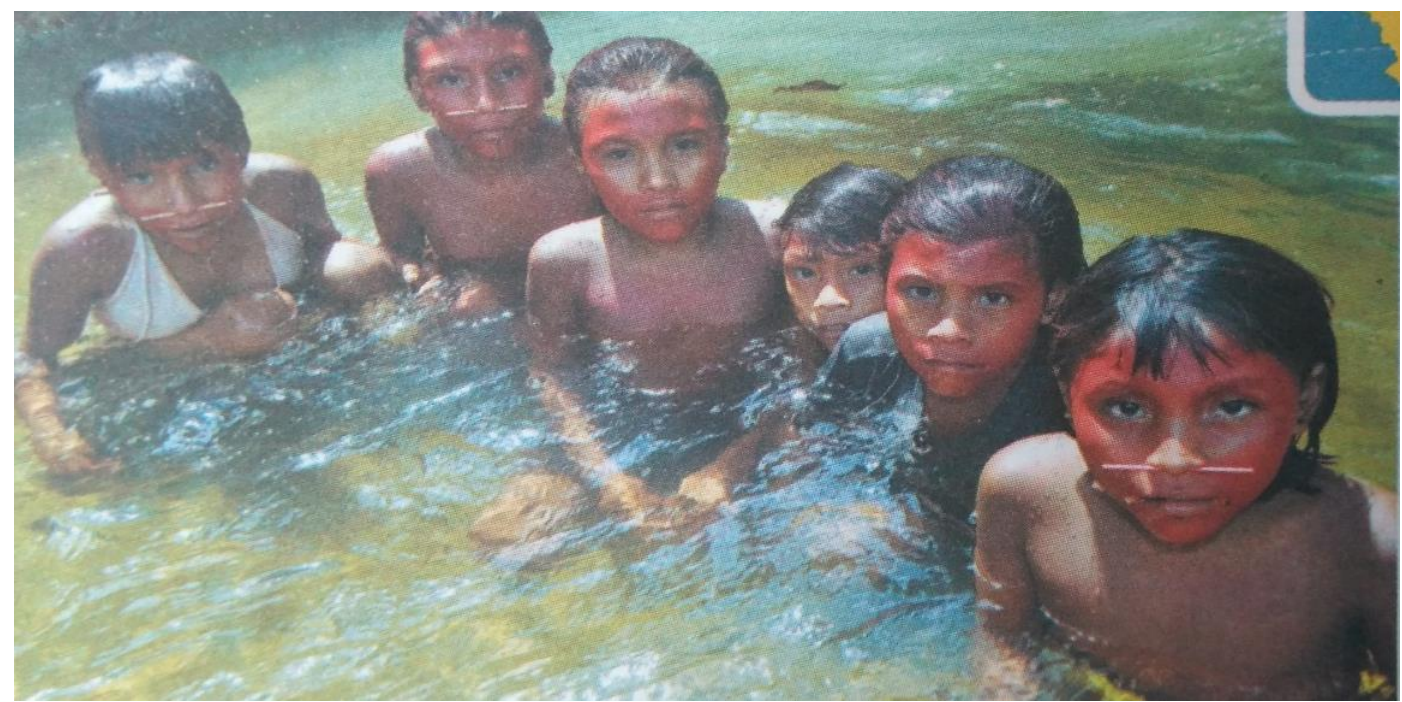

Fonte: Livro Didático do $7^{\circ}$ ano, 2018. 
Figura 6: Ilustração sobre indígenas Baroro realizando ritual.

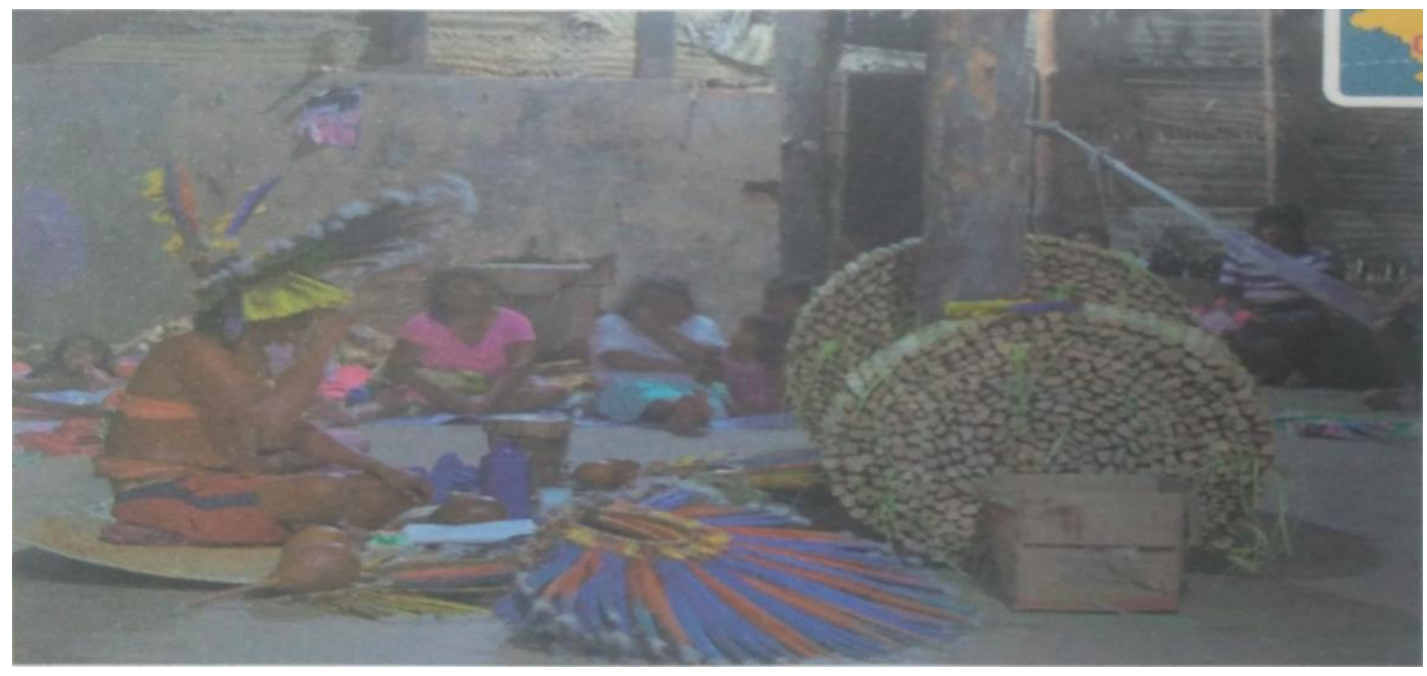

Fonte: Livro Didático do $7^{\circ}$ ano, 2018.

Figura 7: llustração sobre comunidade quilombola no Pará.

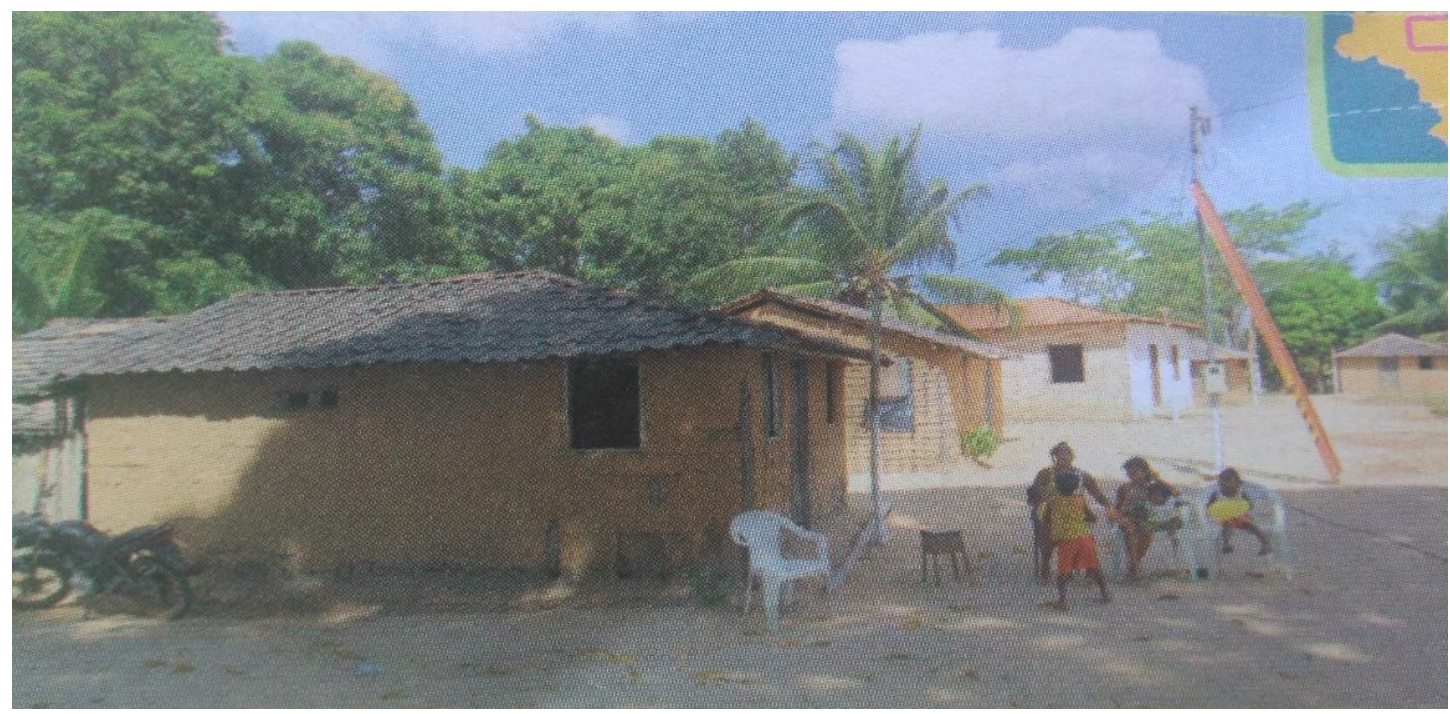

Fonte: Livro Didático do $7^{\circ}$ ano, 2018. 
Figura 8: Indígena acessando a internet na aldeia Wederã.

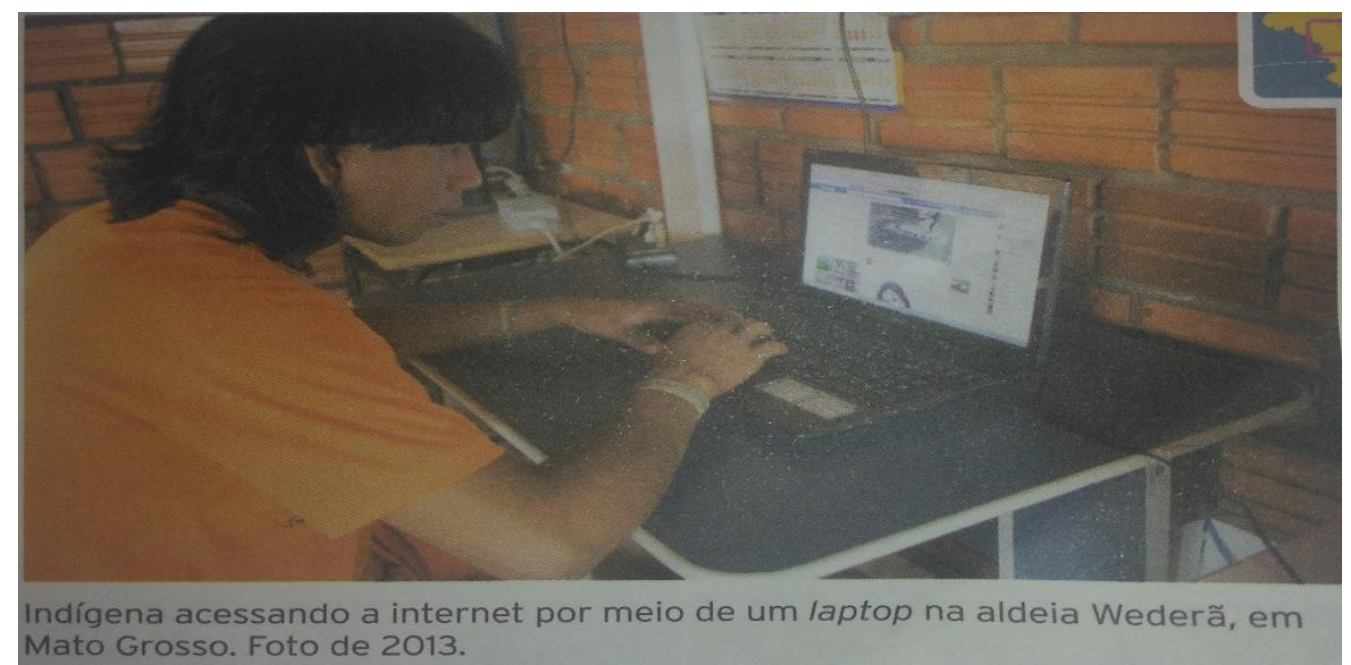

Fonte: Livro Didático do $7^{\circ}$ ano, 2018.

Também no livro do $7^{\circ}$ ano foram representadas com mais 4 ilustrações, a (figura 5) sobre as crianças indígenas, apenas com um texto de apoio abordando sobre a aldeia, outra sobre uma comunidade quilombola no Pará, porém, sem aprofundamento em relação ao conteúdo sobre essas comunidades no interior do Estado. Ainda, outra imagem que chamou atenção foi a (figura 8), o qual o conteúdo aborda sobre a moderna telecomunicação abordando sobre o avanço de formas de comunicação através de sistema digital, como internet, telefonia, o qual colocou representou com um indígena realizando um desses meios de comunicação.

As ilustrações presentes no livro do $8^{\circ}$ ano são dadas somente três vezes, na primeira está presente no capítulo 7 intitulado "África: um continente de contrastes" na página 173 representa um massacre de 80 mil guerreiros africanos. A segunda e terceira estão no capítulo 9 intitulado "África: população e urbanização" na página 221. Representa o cartaz de campanha década da mulher africana, e a outra da representação de Wangari Maathai a líder queniana da defesa do meio ambiente e dos direitos das mulheres. 
Figura 9: Ilustração sobre o massacre de 80 mil guerreiros africanos.

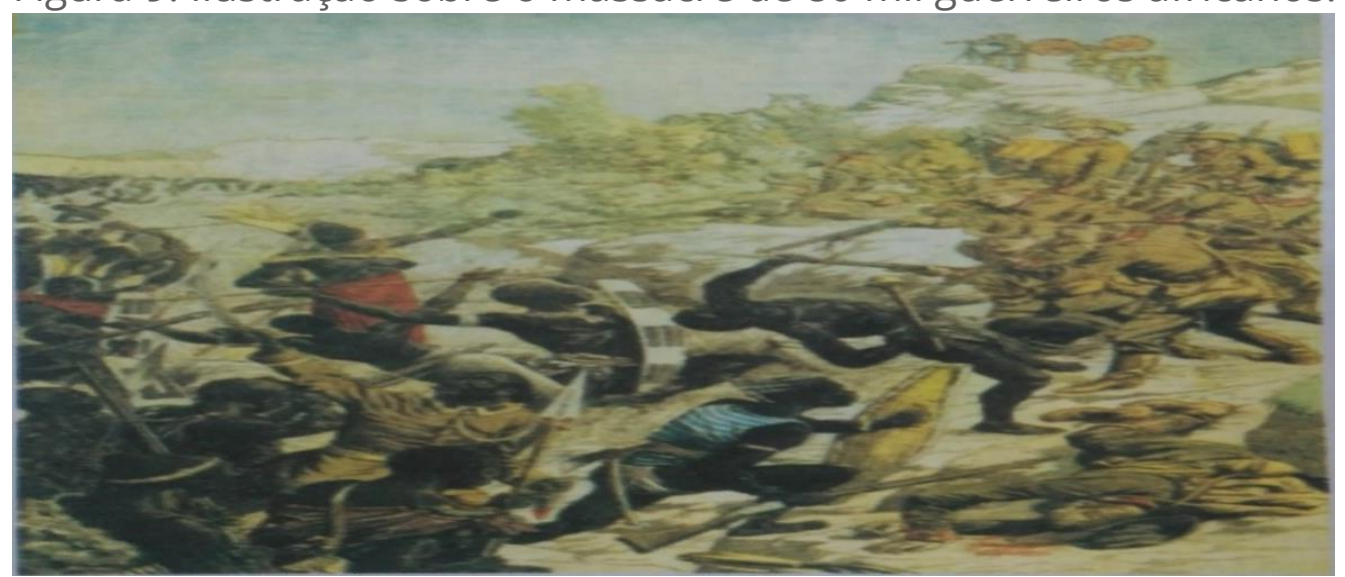

Fonte: Livro Didático do $8^{\circ}$ ano, 2018.

Figura 10 e 11: Ilustração sobre o cartaz da década da mulher negra e de Wangari Maathai.

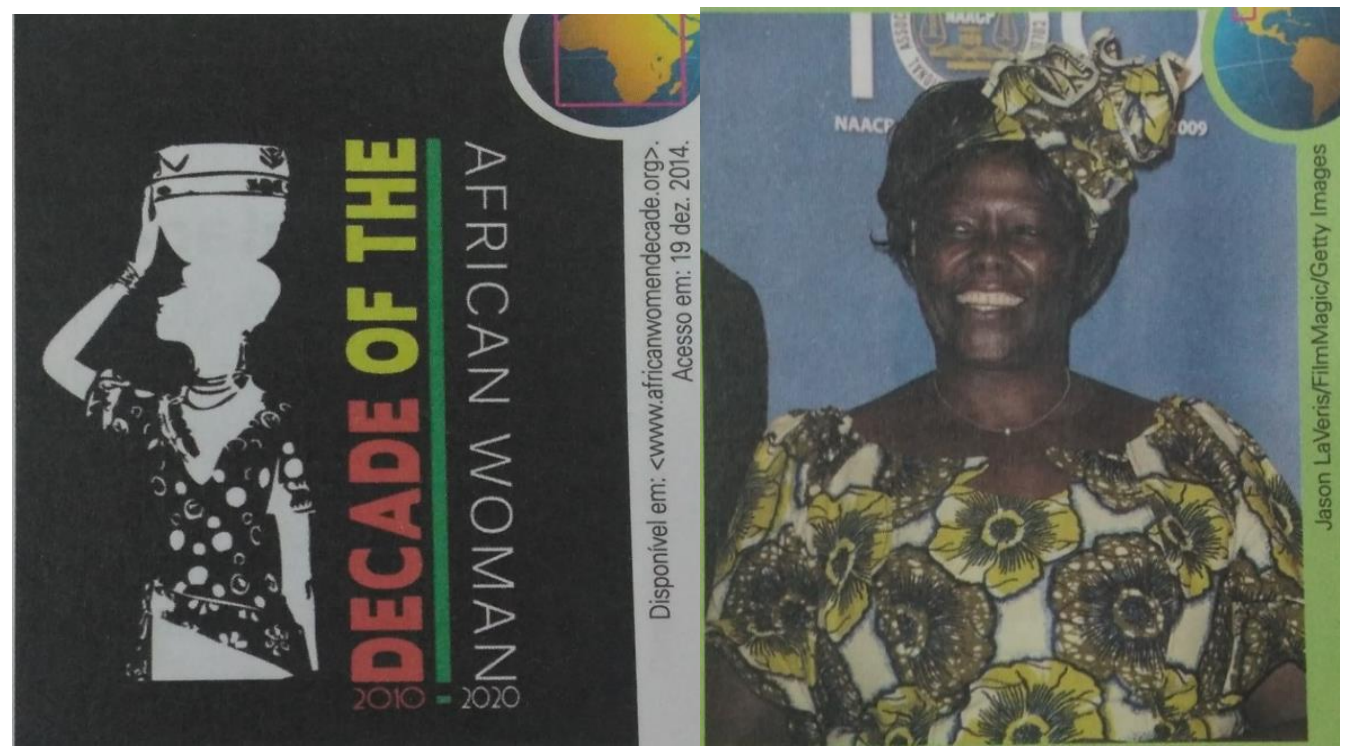

Fonte: Livro Didático do $8^{\circ}$ ano, 2018.

No livro do $9^{\circ}$ ano são apresentadas somente duas vezes, a primeira onde uma representa o Theodoro Sampaio contextualizando sua história, na página 83, outra corresponde sobre os Ciganos que são vítimas do racismo na União Europeia, na página 97 da unidade. Diante disso, as ilustrações estão adequadas para a representatividade racial, se considerarmos o contexto dessas imagens.

Vale ressaltar, não foi identificada nenhuma outra imagem que represente sobre a temática estudada, o que leva a fazer novamente outra observação no aspecto que a coleção em seus quatro volumes, sobre com a dificuldade em 
representar a diversidade étnica da população brasileira pelas ilustrações. Outra observação, ambos capítulos sobre África estão no final do volume do livro didático que número inferior de páginas comparado com os demais volumes, destacando a falta de utilização de figuras para representar a cultura, etnia e conhecimentos sócios científicos africanos.

Figura 12 e 13: Ilustrações sobre Theodoro Sampaio e dos Ciganos.

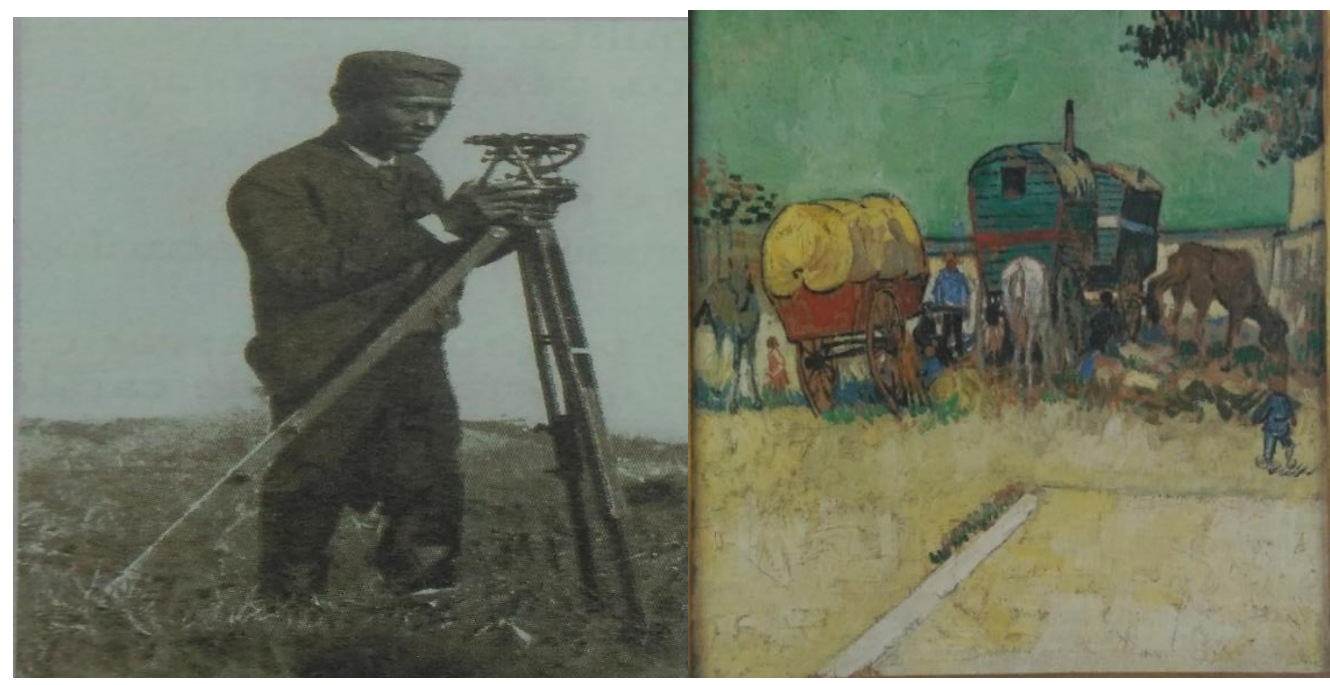

Fonte: Livro Didático do $9^{\circ}$ ano, 2018.

De acordo com a proposta de análise da pesquisa, a coleção Para Viver Juntos, apresenta diversas figuras com temas que podem ser levemente trabalhados na abordagem racial no ensino de Geografia. Contudo, em relação às figuras referentes às questões étnico-raciais, não contribuem efetivamente para a construção de um conhecimento crítico sobre as relações étnico-raciais no mundo em que o aluno vive.

\section{CONSIDERAÇÕES FINAIS}

De acordo com a proposta da pesquisa, verifica-se que existe ainda o padrão em relação às figuras com informações já conhecidas a respeito da temática. Outra observação a destacar é um certo "congelamento" referente à cultura do indígena no Brasil como representa (figuras 3 e 5). Entretanto, na 
coleção foi encontrada outra figura que valorize a visão atual da vivência e dos costumes indígenas. Como de exemplo, indígenas tendo acesso à tecnologia (figuras 1 e 8), porém, sabemos que os conhecimentos e saberes sócios científicos não estão apenas limitado aos usos de tecnologias, atualmente devido às cotas universitárias há uma grande presença desses sujeitos nos espaços das universidades no Brasil. Desta forma, percebe-se o quanto ainda necessita ocorrerem modificações referentes aos conteúdos e figuras da cultura afrobrasileira nos materiais didáticos de Geografia.

As temáticas presentes que estão abordados na seção "mundo aberto" é um ponto positivo para coleção, porém, tal modo é distribuída de forma limitada durante as unidades nos livros. Dessa forma, percebemos que a coleção apresenta o conteúdo em perspectiva apenas para a obrigatoriedade legal perante as leis criadas para o âmbito educacional, ou seja, o livro não intensifica os assuntos durante as unidades, deixando a responsabilidade para o professor que possivelmente pela sua formação inicial não vai realizar ações pedagógicas voltadas para a questão racial.

A pesquisa se mostrou de grande relevância, pois, os estudos voltados para a temática das relações étnico-raciais fazem pensar sobre os temas de matriz africana e afro-brasileira no currículo de acordo com a Lei. 10. 639/03, realizando uma reflexão sobre como os conteúdos nos currículos e materiais didáticos estão sendo desenvolvidos sobre a cultura afro-brasileira.

A temática em alguns momentos na coleção, através das figuras é tratada apenas da perspectiva do eurocentrismo, ou seja, sobre a cultura indígena e afrobrasileira, não são desenvolvidos conteúdos nas unidades sobre os problemas do racismo, preconceito, discriminação e intolerância que ocorrem nos dias atuais, das lutas, dos movimentos sociais que reivindicam direitos pela igualdade em meio a sociedade. Apesar, que no livro do $7^{\circ}$ ano está presente uma figura que retrate sobre o dia da Consciência Negra. Também, não aborda sobre a atualidade dessas comunidades existentes que não estão apenas presentes na 
região Norte e sobre suas características culturais e seus saberes sócios científicos.

Portanto, os livros didáticos voltados para o ensino de Geografia na Educação Básica fazem pouca referência às abordagens e especificidades do campo das relações étnico-raciais. As ausências de discussões sobre as questões que envolvem a temática no ensino de Geografia podem ocasionar o desconhecimento, a criticidade e poucos elementos que podem proporcionar o avanço da área de conhecimento da Geografia humana e cultural.

\section{REFERÊNCIAS}

ANJOS, Rafael Sanzio Araújo dos. A Geografia, a África e Negros Brasileiros. In: MUNANGA, Kabengele (Org.). Superando o racismo na escola. Brasília: Ministério da Educação, Secretaria de Educação Continuada, Alfabetização e Diversidade, 2005, p.173-184.

BRASIL. Lei 10.639/2003, 09 de janeiro de 2003. Altera a Lei nº 9. 394, de 20 de dezembro de 1996. Diário Oficial da União, Poder Executivo, Brasília, 2003. Disponível em: http://www.planalto.gov.br/ccivil 03/leis/2003/l10.639.htm. Acesso em 17 de dez. de 2019.

BRASIL. LEI 11.645/2008, 10 de março de 2008. Altera a Lei n 9.394, de 20 de dezembro de 1996. Diário Oficial da União, Poder Executivo, Brasília, 2008. Disponível em: http://www.planalto.gov.br/ccivil 03/ Ato2007-2010/2008/Lei/L11645.htm. Acesso em 17 de dez. de 2019.

CARDOSO, Paulino de Jesus, F; RASCKE, Karla Leandro. Lei Federal 10.639/03, discussão de conceitos: multiculturalismo, diversidade. Ações afirmativas, racismo, preconceito, afrodescendente, negro, entre outros. In: CARDOSO, Paulino de Jesus, F; RASCKE, Karla Leandro. (Orgs). Formação de professores: promoção e difusão de conteúdos sobre história e cultura afro-brasileira e africana. $1^{\text {a }}$ ed. Florianópolis: Editora DIOESC, 2014. p. 12-27.

CANDAU, Vera Maria Ferrão. Diferença culturais, interculturalidade e educação em direitos humanos. Educ. Soc, Campinas, v. 33, n. 118, p. 235-250, jan.-mar. 2012.

GOMES, Nilma Lino. Diversidade Étnico-racial: por um projeto educativo emancipatório. In: FONSECA, M. V. et al. (Orgs). Relações étnico-raciais e educação no Brasil. Belo Horizonte: Editora Mazza Edições, 2011. p. 39-60. 
GOMES, Nilma Lino. A questão racial na escola: desafios colocados pela implementação da lei 10639/03. In: MOREIRA, Antonio Flávio \& CANDAU, Vera Maria. (Orgs.). Multiculturalismo diferenças culturais e práticas pedagógicas. $10^{a}$ edi. Petrópolis, RJ: Vozes, 2013, p. 67-89.

LUCINDO, Willian Robson S. Histórico do Movimento Negro no Brasil, luta e resistência às Políticas de Ação Afirmativas, a Declaração de Durban até s Lei 10.639/03: a dívida social do Brasil com a população negra após o 13 maio. In: Formação de professores: promoção e difusão de conteúdos sobre história e cultura afro-brasileira e africana. (Orgs). CARDOSO, Paulino de Jesus, F; RASCKE, Karla Leandro. $1^{\text {a }}$ ed. Florianópolis: Editora DIOESC, 2014. p. 60-75.

MULLER, Maria Lúcia R. Formação de professores e perspectivas para a implantação da lei 10.639/03. In: SOUZA, Maria Elena Viana. (Org). Relações raciais no cotidiano escolar: diálogos com a lei 10.639/03. Rio de Janeiro, Editora Rovelle, 2009. p. 31-46.

MARQUES, Eugenia Portela S; CALDERONI, Valeria Aparecida M. de Oliveira. Os deslocamentos epistêmicos trazidos pelas leis 10.639/2003 e 11.645/2008: possibilidades de subversão à colonialidade do currículo escolar. Catalão-GO, v. 16, n. 2, p. 299-315, jul./dez. 2016.

MARTINS, Alan Bizerra. As relações étnico-raciais nos livros didáticos de geografia dos anos finais do ensino fundamental. 2018. Monografia (Geografia)-Universidade Federal do Sul e Sudeste do Pará, Marabá-PA, 2018.

MARTINS, Alan Bizerra; GOMES, Ana Clédina R. Preconceito e discriminação no espaço escolar: um estudo de caso com base no perfil de alunos do $8^{\circ}$ e $9^{\circ}$ ano do ensino fundamental In: VII Fórum Internacional de Pedagogia, Imperatriz. Anais...Imperatriz: editora realize, 2016, p. 1-6.

SANTOS, Renato Emerson dos. O ensino de Geografia do Brasil e as relações raciais: reflexões a partir da Lei 10.639. In: SANTOS, Renato E. dos. (Org). Diversidade, espaço e relações étnico-raciais: 0 Negro na Geografia do Brasil. $2^{a}$ edi. Belo Horizonte: Gutenberg, 2009, p. 21-40.

SILVA, Ana Célia da. A Desconstrução da Discriminação no Livro Didático. In: MUNANGA, Kabengele (Org.). Superando o racismo na escola. Brasília: Ministério da Educação, Secretaria de Educação Continuada, Alfabetização e Diversidade, 2005, p. 21-38.

SIMÃO, Maristela dos Santos; BELÉSSIMO, Angelo Renato. Relações raciais na escola: currículo e responsabilidades, livro didático, mídias e escola. In: CARDOSO, Paulino de Jesus, F; RASCKE, Karla Leandro. (Orgs). Formação de professores: promoção e difusão de conteúdos sobre história e cultura afro-brasileira e africana. $1^{\text {a }}$ ed. Florianópolis: Editora DIOESC, 2014. p. 43-59. 
SOUZA, Maria Elena Viana. Relações raciais no ensino superior: experiências de ensino/aprendizagem e pesquisa. In: SOUZA, Maria Elena Viana. (Org). Relações raciais no cotidiano escolar: diálogos com a lei 10.639/03. Rio de Janeiro, Editora Rovelle, 2009. p. 63-87. 